\title{
PENGARUH PENDIDIKAN KESEHATAN DENGAN MEDIA AUDIO VISUAL TERHADAP PENGETAHUAN DAN SIKAP ANAK USIA SEKOLAH TENTANG PENYAKIT DEMAM BERDARAH
}

\section{THE EFFECT OF HEALTH EDUCATION WITH AUDIOVISUAL MEDIA ON KNOWLEDGE AND ATTITUDE OF SCHOOL AGES ABOUT BLOOD FEVER DISEASE}

\author{
DwiAprilinaAndriani \\ Poltekkes Kemenkes Banten \\ Korespondensi:dwiaprilinaa@gmail.com
}

\begin{abstract}
Transmission of dengue virus infection that occurs through the mosquito vector of the genus Aedes (especially A. Aegypti and A. Albopictus).efforts to prevent dengue fever by means of health promotion in schools have a great effect. The role of media in learning especially in children's education is based on what they see, hear or experience. Therefore message messages through hearing and messaging through visualization or audio-visual media. This study was a quasi-experimental study with a pre-test-post test with a control group. The study was conducted in August 2018 on 46 respondents. The results of the independent $t$-test on social education on the knowledge of school students $(p=0.025)$ and there was no effect of health education on students $(p=0.510)$ about dengue fever.
\end{abstract}

Keywords: knowledge, attitude, dengue fever, children, audiovisual

\begin{abstract}
ABSTRAK
Penularan infeksi virus dengue terjadi melalui vektor nyamuk genus Aedes (terutama A. Aegypti dan A. Albopictus). upaya pencegahan demam berdarahdengan cara promosi kesehatan di sekolah mempunyai efek yang besar. Peran media dalam pembelajaran khususnya dalam pendidikan anak usia dini didasari oleh apa yang mereka lihat, dengar, atau pun alami. Oleh karena itu penerimaan pesan pembelajaran melalui pendengaran dan memungkinkan penciptaan pesan belajar melalui visualisasi atau media audio visual. Penelitian ini adalah penelitian kuasi eksperimen dengan pretest-posttest with control group. Penelitian dilakukan pada bulan Agustus 2018 pada 46 responden. Hasil uji $t$-test independent menunjukkan adanya pengaruh pendidikan kesehatan terhadap pengetahuan anak usia sekolah $(\mathrm{p}=0,025)$ dan tidak ada pengaruh pendidikan kesehatan terhadap sikap anak usia sekolah $(\mathrm{p}=0,510)$ tentang penyakit demam berdarah.
\end{abstract}

Kata Kunci: pengetahuan, sikap, demam berdarah, anak, audiovisual 


\section{PENDAHULUAN}

Demam berdarah dengue (DBD) menduduki peringkat utama penyakit rawat inap di kota Tangerang tahun 2015 yaitu sebanyak 552 kasus. Walaupun pada tahun 2015, kasus DBD menurun yaitu 518 kasus, namun angka kesakitan DBD meningkat pada tahun 2015 dan juga masih di bawah target dari Kemenkes (Depkes RI, 2016).

Penularan infeksi virus dengue terjadi melalui vektor nyamuk genus Aedes (terutama A. Aegypti dan A. Albopictus). Peningkatan kasus setiap tahunnya berkaitan dengan sanitasi lingkungan dengan tersedianya tempat perindukan bagi nyamuk betina yaitu bejana yang berisi air jernih (bak mandi, kaleng bekas, dan tempat penampungan air lainnya). Krianto (2009) menyebutkan bahwa upaya pencegahan dengan cara promosi kesehatan di sekolah mempunyai arti yang strategis.

Peran media dalam pembelajaran khususnya dalam pendidikan anak semakin penting mengingat pemikiran anak didasari oleh apa yang mereka lihat, dengar, atau pun alami. Anak mampu mengklasifikasi benda dan perintah dan menyelesaikan masalah secara konkret dan sistematis berdasarkan apa yang mereka terima dari lingkungannya (Wong, 2009).

Media audio visual dapat memperjelas hal-hal yang abstrak dan memberikan penjelasan yang lebih realistik, pesan lebih cepat ditangkap dan mudah diingat, dan dapat diputar berulang-ulang untuk menambah kejelasan sehingga meningkatkan efektifitas dan efisiensi proses pembelajaran (Munadi, 2008). Penelitian yang dilakukan oleh Kapti dkk (2013) menunjukkan bahwa ada perbedaaan pengetahuan dan sikap setelah diberikan penyuluhan kesehatan dengan media audio visual. Dari hal tersebut peneliti ingin mengetahui pengaruh media audio visual terhadap pengetahuan dan sikap anak usia sekolah terkait demam berdarah guna untuk membantu pencegahan penyakit tersebut.

Penelitian ini bertujuan untuk mengetahui pengaruh pendidikan kesehatan dengan media audio visual terhadap pengetahuan dan sikap anak usia sekolah tentang penyakit demam berdarah.

\section{METODE}

Penelitian ini menggunakan desain penelitian quasi eksperiment dengan 
pendekatan pretest-posttest with control group. Kelompok intervensi diberikan intervensi berupa pemberian informasi terkait kesehatan dengan menggunakan alat bantu video dengan materi penyebab demam berdarah.Populasi penelitian ini adalah siswa kelas dua SD Taman Sukarya 1 dan 2 kota Tangerang dengan sampel sebanyak 23 orang pada masingmasing kelompok. Penelitian dilakukan pada bulan Agustus 2018 dan menggunakan kuesioner pengetahuan dan sikap.

Masing-masing kelompok dilakukan pengukuran pengetahuan dan sikap sebanyak dua kali. Sebelumnya responden diberikan inform consent yang disetujui pula oleh orangtua anak. Mula-mula dilakukan pengukuran pengetahuan dan sikap anak terhadap penyakit demam berdarah baik di kelompok kontrol maupun perlakuan, selanjutnya pada kelompok perlakuan dilakukan intervensi pemberian media audio visual terkait penyakit demam berdarah kurang lebih 15 menit. Pada pertemuan selanjutnya masing-masing tiga hari kemudian dilakukan kembali pengukuran pengetahuan dan sikap dengan menggunakan kuesioner yang sama.

$$
\text { Analisis data yang }
$$
digunakanyaitut-test independent dengan menggunakan program komputer dengan tingkat kepercayaan $95 \% \quad(\mathrm{p} \leq$ 0,05).Peneliti dibantu oleh peneliti pendamping, dimana peneliti pendamping sebelumnya sudah dilakukan pelatihan dan persamaan persepsi antara peneliti dan peneliti pendamping.

\section{HASIL DAN PEMBAHASAN}

Tabel 1.

KarakterResponden $(n=46)$

\begin{tabular}{cccccc}
\hline Variabel & Kelompok & Mean & Simpangan Baku & Min-maks & Nilai p \\
\hline Usia & Perlakuan & 7,39 & 0,499 & $7-8$ & 0,577 \\
\cline { 2 - 5 } & Kontrol & 7,83 & 0,576 & $7-9$ & \\
\hline Jenis & Perlakuan & 1,48 & 0,511 & $1-2$ & \multirow{2}{*}{1,000} \\
\cline { 2 - 5 } Kelamin & Kontrol & 1,52 & 0,511 & $1-2$ & \\
\hline
\end{tabular}

Tabel di atas menujukkan bahwa rata-rata usia responden kelompok control dan perlakuan tidak jauh berbeda. Selain itu dapat dilihat bahwa rata-rata jenis kelamin pada 
kedua kelompok juga tidak jauh berbeda Hal ini dibuktikan dengan nilai homogenitas pada kedua variabel menunjukkan angka > 0,05 yang berarti varian di antara dua kelompok sama.

Tabel 2. Distribusi Frekuensi Skor Pengetahuan Respomden di SD Taman Sukarya 1 dan 2 Tahun $2018(n=46)$

\begin{tabular}{ccccccc}
\hline Kelompok & & Mean & Median & Simpanganbaku & Min & Maks \\
\hline \multirow{2}{*}{ Perlakuan } & Pre tes & 13.52 & 15 & 3.088 & 4 & 15 \\
\cline { 2 - 7 } & Postes & 14.43 & 15 & 1.647 & 8 & 16 \\
\hline \multirow{2}{*}{ Kontrol } & Pre tes & 8.83 & 9 & 3.084 & 2 & 14 \\
\cline { 2 - 8 } & Postes & 10.78 & 10 & 2.392 & 7 & 15 \\
\hline
\end{tabular}

Tabel 3. Distribusi Frekuensi Skor Sikap Responden di SD Taman Sukarya 1 dan 2

Tahun $2018(\mathrm{n}=46)$

\begin{tabular}{ccccccc}
\hline Kelompok & & Mean & Median & $\begin{array}{c}\text { Simpanganba } \\
\text { ku }\end{array}$ & Min & Maks \\
\hline \multirow{2}{*}{ Perlakuan } & Pre tes & 8.22 & 9 & 1.953 & 3 & 9 \\
\cline { 2 - 7 } & Postes & 8.30 & 9 & 1.550 & 5 & 9 \\
\hline \multirow{2}{*}{ Kontrol } & Pre tes & 7.78 & 8 & 0.850 & 5 & 4 \\
\cline { 2 - 7 } & Postes & 6.91 & 7 & 1.443 & 9 & 9 \\
\hline
\end{tabular}

Dari hasil analisis skor pada kelompok kontrol, terdapat peningkatan rata-rata skor pengetahuan $(1,95)$ pada kelompok kontrol, namun tidak terjadi peningkatan pada skor sikap pada responden. Sedangkan pada kelompok perlakuan terjadi peningkatan rata-rata skor pengetahuan maupun sikap, yaitu 0,91 untuk skor pengetahuan dan 0.08 untuk skor sikap. Artinya adalah pada kelompok yang diberikan pendidiikan kesehatan dengan media audio visual terjadi peningkatan pengetahuan maupun sikap pada anak usia sekolah.

Hasil penelitian ini sejalan dengan penelitian sebelumnya yang dilakukan oleh Rahmawati dkk (2007) yang meneliti tentang Pengaruh Penyuluhan dengan Media Audio Visual terhadap Peningkatan Pengetahuan, Sikap, dan Perilaku Ibu Balita Gizi Kurang dan Buruk di Kabupaten Kotawaringin Barat Provinsi Kalimantan Tengah. Penelitian tersebut mendapatkan hasil bahwa setelah dilakukan penyuluhan dengan media audio visual terjadi peningkatan perilaku yang signifikan sebesar 2,02 (poin) dibandingkan kelompok kontrol (1 poin) dan menggunakan modul dengan hasil yang tidak signifikan (2.1448). 
Tabel 4. Pengetahuan anak usia sekolah setelah diberikan pendidikan kesehatan dengan media audio visual tentang penyakit demam berdarah tahun $2018(n=46)$

\begin{tabular}{lcccc}
\hline \multicolumn{1}{c}{ Kelompok } & Mean & SD & SE & P value \\
\cline { 1 - 4 } Perlakuan & 14,33 & 1,6863 & 0,367 & 0,025 \\
\cline { 1 - 3 } Kontrol & 10,78 & 2,392 & 0,499 & \\
\hline
\end{tabular}

Tabel 5. Sikap anak usia sekolah setelah diberikan pendidikan kesehatan dengan media audio visual tentang penyakit demam berdarah tahun $2018(n=46)$

\begin{tabular}{lcccc}
\hline \multicolumn{1}{c}{ Kelompok } & Mean & SD & SE & P value \\
\hline Perlakuan & 8,43 & 1,432 & 0,313 & 0,510 \\
\cline { 1 - 3 } Kontrol & 6,91 & 1,443 & 0,301 & \\
\hline
\end{tabular}

Dari hasil penelitian ini diketahui pula terdapat pengaruh pendidikan kesehatan dengan media audio visual terhadap pengetahuan anak usia sekolah yang dibuktikan dengan hasil uji t-test independent dengan nilai $\mathrm{p}=0,025(<$ 0,05) yang menunjukkan adanya pengaruh pendidikan kesehatan dengan media audio visual terhadap pengetahuan anak usia sekolah tentang penyakit demam berdarah. Penelitian ini diperkuat dengan pendapat Citerawati (2012) yang menyatakan bahwa dengan penggunaan audio visual, cara penyampaian dan penerimaan bahan pendidikan menjadi lebih mudah., Hal ini disebabkan karena $83 \%$ pengetahuan manusia disalurkan melalui penglihatan dan $11 \%$ melalui pendengaran. Strategi melalui audio visual juga telah diketahui dapat mempengaruhi kognitif seseorang (Anderson dalam Waryanto 2007).

Berbeda dengan pengetahuan yang mendapatkan nilai $\mathrm{p}$ kurang dari 0,05 , untuk uji t-test independent yang menilai sikap anak usia sekolah didapatkan nilai $\mathrm{p}=0,510(>0,05)$. Peningkatan skor sikap anak usia sekolah terhadap penyakit demam berdarah pada kelompok perlakuan setelah diberikan pendidikan keseshatan ternyata tidak memberikan pengaruh yang signifikan. Hal ini dapat disebabkan karena tidak adanya pengalaman langsung terkait materi demam berdarah yang diberikan setelah pemberian pendidikan kesehatan dengan media audio visual, salah satunya adalah tentang pencegahan demam berdarah.

Metode demonstrasi memberikan kesempatan kesada siswa anak usia 
skolah untuk nenunjukkan sesuatu dengsn lebih konkret. Dalam strategi pembelajaran, demonstrasi dapat digunakan untuk mendukung keberhasilan strategi pembelajaran. Dengan cara mengamati secara langsung siswa akan memiliki kesempatan untuk membandingkan antara teori dan kenyataan. Dengan demikian siswa akan lebih meyakini kebenaran materi pembelajaran (Departemen Pendidikan Nasional, 2008). Darmiastuty (2004) juga menyatakan bahwa proses belajar dengan metode demonstrasi memicu anak untuk lebih mendalami pengetahuan yang mereka miliki dengan cara mengaktifkan kembali pengetahuan yang dimiliki, mengolah pengetahuan tersebut kemudian mengorganisasi pengetahuan tersebut sehingga pengetahuan yang diperoleh dapat tertahan erat dalam sistem penyimpanan dan sulit dilupakan.

\section{SIMPULAN}

Hasil uji beda dengan menggunakan t-Test independent dengan tingkat kepercayaan 95\% ( $\alpha \leq$ $0,05)$ yang dilakukan untuk mengetahui pengaruh pendidikan kesehatan dengan audio visual terhadap pengetahuan dan sikap anak usia sekolah terhadap penyakit demam berdarah diperoleh nilai $\mathrm{p}$ pengetahuan $=0,025$ (kurang dari nilai $\alpha=0,05$ ), jadi H0 ditolak dan $\mathrm{p}$ sikap $=0,510$ (lebih dari nilai $\alpha=$ 0,05), jadi H0 diterima. Sehingga dapat disimpulkan ada pengaruh pendidikan kesehatan dengan audio visual terhadap pengetahuan anak usia sekolah, namun tidak ada pengaruh pendidikan kesehatan dengan audio visual terhadap sikap anak usia sekolah tentang penyakit demam berdarah.Bagi Peneliti Selanjutnya agar mencoba meneliti pengaruh penggunaan audio visual dan strategi pembelajaran lainnya misalnya demonstrasi dalam meningkatkan sikap siswa tentang penyakit demam berdarah.

\section{UCAPAN TERIMA KASIH}

Terima kasih penulis sampaikan kepada Poltekkes Kemenkes Banten yang telah membantu dalam Proses Pembiayaan.

\section{DAFTAR PUSTAKA}

Citerawati SY, Y.W. 2012. Media Penyuluhan, (online), (http://adingpintar.files.wordpres s.com/2012/03/mediapenyuluhan.pdf, diakses 8 November 2018) 
Darmiastuty, Meita. 2004. Efektivitas metode ceramah tanya jawab dan simulasi dalam meningkatkan pengetahuan dan sikap ibu tentang pencegahan dini penyalahgunaan narkoba pada remaja SLTP 1 Borobudur Kabupaten Magelang. Semarang: Pasca Sarjana Universitas Diponegoro

Departemen Pendidikan Nasional. 2008. Strategi Pembelajaran dan Pemilihannya. Jakarta : Direktorat Tenaga Kependidikan Direktorat Jenderal Peningkatan Mutu Pendidik Dan Tenaga Kependidikan

Dinas Kesehatan Kota Tangerang. (2016). Profil Kesehatan Kota Tangerang Tahun 2015. Retrieved from : website Departemen Kesehatan RI : www.depkes.go.id/resources/dow nload/profil/PROFIL_KAB_KOT A_2015/3671_Banten_Kota_Tang erang_2015.pdf

Kapti, R.E., Rustina, Y., Widyatuti. 2013. Efektifitas Audiovisual sebagai Media Penyuluhan Kesehatan Terhadap Peningkatan Pengetahuan dan Sikap Ibu dalam Tatalaksana Balita dengan Diare di Dua Rumah Sakit Kota Malang. Jurnal Ilmu Keperawatan, 1 (1)

Krianto, T. 2009. Tidak semua anak sekolah mengenal demam berdarah. Makara Kesehatan, 13: 2 (99-103)

Munadi, Y. 2008. Media Pembelajaran, Sebuah Pendekatan Baru.Ciputat : Gaung Persada Press

Rachmawati, I., Sudargo T., Paramastri, I. 2007. Pengaruh Penyuluhan dengan Media Audio Visual Terhadap Peningkatan Pengetahuan, Sikap, dan Perilaku Ibu Balita Gizi Kurang dan Buruk di Kabupaten Kotawaringin Barat Propinsi Kalimantan Tengah. JurnalGiziKlinik Indonesia, 4 (2) : 69-77

Waryanto, N. H. 2007. Penggunaan Media Audio Visual dalam 


\author{
Menunjang Pembelajaran. \\ Makalah disajikan dalam \\ Pengabdian pada Masyarakat \\ untuk Guru-Guru SMA, FMIPA \\ UNY, Bantul, 18 Januari 2007
}

